\title{
Efficacy of SEVISTA (Ormeloxifene) in treatment of mastalgia and fibrocystic breast disease
}

\author{
Vandana Bansal $^{1,2 *}$, Arpit Bansal ${ }^{3}$, Ashwani Kumar Bansal $^{3}$
}

\author{
${ }^{1}$ Guru Gobind Singh Memorial Vanadana Women's Hospital, Allahabad, U.P., India. \\ ${ }^{2}$ Department of Gynecology, ${ }^{3}$ Department of Surgery, Jeevan Jyoti Hospital, Allahabad, U.P., India
}

Received: 23 May 2015

Accepted: 07 June 2015

\section{*Correspondence:}

Dr. Vandana Bansal,

E-mail: bansal.drvandana@gmail.com; drvandanaresearch@gmail.com

Copyright: (C) the author(s), publisher and licensee Medip Academy. This is an open-access article distributed under the terms of the Creative Commons Attribution Non-Commercial License, which permits unrestricted non-commercial use, distribution, and reproduction in any medium, provided the original work is properly cited.

\begin{abstract}
Background: Mastalgia and fibrocystic breast disease is common in women. Ormeloxifene (SEVISTA) is a weak oestrogen receptor (ER) agonist, a strong ER antagonist (SERA) and therefore a selective ER modulator (SERM) used in the treatment of the disease. Aim of study was to see the efficacy of ormeloxifene in women with pain in breast associated with or without fibrocystic breast disease.

Methods: This was a randomized control trial of oral ormeloxifene $30 \mathrm{mg}$ alternate day for 3 month in patients of 20 -50 years old with breast pain and fibrocystic (without cancer). The pain was accessed by visual analogue scale and nodularity grade on a 5 - point.

Results: Total 203 patients were completed the study. The mean age was $32.8 \pm 8.35$ years. The mean pain level was continuously decrease over 5 visit (5.8 to 0.86 ) and there was significant improvement was observed in the nodularity grades i.e. at beginning of treatment 1 and 2 nodularity were seen in $62(30.5 \%)$ patients where as grades 3,4 and 5 were seen in 141(69.5\%) and at the end of six month it was $188(92.6 \%)$ patients had grades 1 and 2 and only 15 (7.4\%) had grade 3, 4 and 5 nodularity.

Conclusion: SEVISTA (Ormeloxifene) showed significant efficacy for the treatment of mastalgia and fibrocystic breast disease.
\end{abstract}

Keywords: Mastalgia, Fibrocystic, SERM, Ormeloxifene

\section{INTRODUCTION}

Mastalgia (breast pain) was described in the medical literature as early as 1829 and is a common complaint amongst women. ${ }^{1}$ The women are commonly suffers from fibrocystic breast changes as well as mastalgia. They may occur separately or in combination. ${ }^{2}$ Mastalgia occur due to hormonal imbalance - oestrogen excess, progesterone deficiency, changes in progestin/oestrogen ratio, differences in receptor sensitivity, disparate secretion of follicle-stimulating hormone (FSH) and luteinizing hormone (LH), low androgen levels, and high prolactin levels have all been implicated as the cause for mastalgia. Fibrocystic Breast Disease (FCBD) is the most common non-cancerous breast disease in women. The term, "FCBD" actually covers a broad range of conditions from painful breasts with solid, lumpy, thickened areas to cysts. Pain from FCBD can occur at any time of your cycle. Many women of childbearing age --about 20 to 45 years of age--have FCBD. Physicians find evidence of FCBD in about one third of women in that age group. ${ }^{3}$ Fibrocystic changes and mastalgia are two different things although they commonly occur together. They can also occur separately, making the association between breast pain and fibrocystic histology inconsistent. ${ }^{4} \mathrm{~A}$ wide variety of therapies are used, but danazol (antigonadotropin) is the most commonly used by $75 \%$ of surgeons. A recently published meta-analysis of drugs for 
the treatment of mastalgia included bromocriptine, tamoxifen, evening primrose oil (EPO) and danazol. ${ }^{5}$ Several agents such as vitamins B6 and E, diuretics, gamolenic acid, non-steroidal anti-inflammatory drugs and caffeine withdrawal have been tried have been tried in past but not found to be effective in randomized studies. Similarly, progesterone creams, tablets and injectables were discarded after randomized studies. Oral contraceptive pills generally contain low doses of ethinyl oestradiol and an oral progestogen and have shown beneficial effects. A new agent called ormeloxifene (Centchroman) is a weak oestrogen receptor (ER) agonist, a strong ER antagonist (SERA) and therefore a selective ER modulator (SERM). Ormeloxifene has previously been used in 42 women with mastalgia who reported $90 \%$ improvement at a dose of $30 \mathrm{mg}$ taken on alternate days. It was also reported to lead to complete disappearance of fibroadenoma in $40 \%$ women after 3 months of treatment. ${ }^{6}$ In a randomized trial including 81 women, it was found to be superior to danazol for the treatment of mastalgia. ${ }^{7}$ We studied the efficacy of ormeloxifene in women with pain in breast associated with or without fibrocystic breast disease.

\section{METHODS}

This was randomized; blind clinical trial was done during 2012-2015 at the Department of Gynecology, Jeevan jyoti Hospital and Guru Govind Singh Memorial Women Hospital, Allahabad, Uttar Pradesh, India.

\section{Inclusion criteria}

Women in the age group of 20-50 years with cyclical or non-cyclic breast pain and nodularity were considered for inclusion in the study. If the patient was $>35$ years of age, a thorough clinical examination of the breast was done followed by bi-planer mammography. Demographic variables, clinical history, general examination and breast examination were carefully recorded on a pre-designed proforma. All patients were given a simple daily breast pain self-recording chart and those with severe cyclical breast pain that continued for more than 10 days in a month were included in the study. Informed written consent was obtained from all patients.

The patients should be given oral ormeloxifene (SEVISTA) $30 \mathrm{mg}$ twice a week for 3 month.

\section{Exclusion criteria}

Patients were excluded from the study if they found suspicious of cancer after clinical, imaging and cytological examination. Patients taking alternative treatment, lactating women, those planning a pregnancy or taking other oral contraceptive pills, women suffering from polycystic ovarian disease, other hormonal abnormalities requiring additional investigations, and liver and kidney problems were also excluded from the study.
Informed written consent was taken by all patients and they were free to withdraw from the study at any time.

For assessment of breast nodularity, Lucknow-Cardiff scale was used. This scale is a 5-point ordinal scale depicting increasing order of nodularity shown schematically in the upper outer quadrants of a paired breast. Grade 0 indicates a smooth textured breast with extreme extent of normalcy and grade 4 the maximum nodularity.

\section{Follow-up}

Breast pain and nodularity were assessed at the start of the active treatment on follow-up at 1,2, 3 and 6 months. At each visit pain and nodularity charts were assessed. The tablet count and self-reporting were taken as compliance. Any side-effects experienced by the patients were recorded at each visit.

The outcomes were based on global assessment of patient's condition and side effect.

\section{RESULTS}

We included 221 patients in the study. In which 18 patients not completed the all visit thus those patients were excluded from the study. Hence in study we consider only 203 patients. The mean age was $32.8 \pm 8.35$ years.

\section{Pain assessment}

The mean pain score was considerably decreases till three month and after three months when treatment was stopped. There was significant decrease in pain score after six month (Table 1, Figure 1).

Table 1: Mean pain assessment at successive visit for SEVISTA.

\begin{tabular}{|ll|}
\hline Visit & $\begin{array}{l}\text { Mean pain } \\
\text { score }\end{array}$ \\
\hline At beginning of treatment & 5.82 \\
\hline At the end of first month & 4.76 \\
\hline At the end of second month & 2.08 \\
\hline At the end of third month & 1.21 \\
\hline At the end of sixth month & 0.86 \\
\hline
\end{tabular}

\section{Nodularity changes}

As observation grades 1 and 2 nodularity were seen in 62 $(30.5 \%)$ patients where as grades 3,4 and 5 were seen in $141(69.5 \%)$. At the end of third month of treatment, 170 $(83.7 \%)$ had grades 1 and 2 while grades 3,4 and 5 were seen only in $33(16.3 \%)$ patients. After two month without treatment (At the end of sixth month) 188 (92.6\%) patients had grades 1 and 2 and only $15(7.4 \%)$ had grade 3,4 and 5 nodularity. There was significantly 
greater improvement in the grade of nodularity in the third and sixth month (Table 2). There was improvement occur in grades of nodularity on every visit was observed. (Figure 2)

\section{Pain assessment}

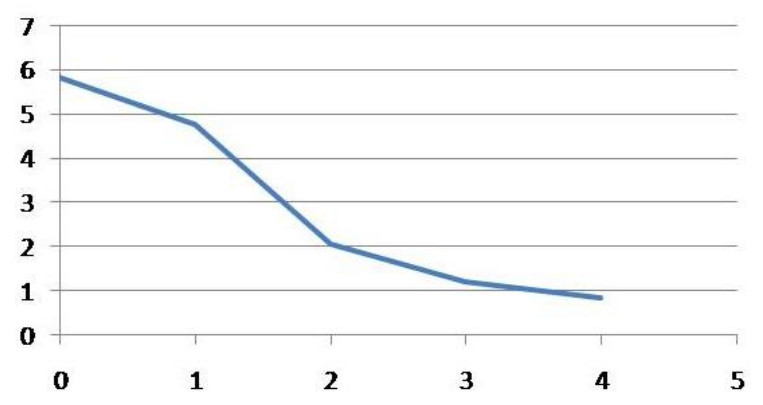

Figure 1: Pain assessment by visual analogue.

Table 2: Frequency (probability) of benign breast nodularity grade in patients receiving SEVISTA before treatment and subsequent visit.

\begin{tabular}{|c|c|c|c|c|c|}
\hline \multirow{2}{*}{ Visit } & \multicolumn{5}{|c|}{ Grade of breast nodularity } \\
\hline & 1 & 2 & 3 & 4 & 5 \\
\hline $\begin{array}{l}\text { At beginning } \\
\text { of treatment }\end{array}$ & $\begin{array}{l}21 \\
(0.085)\end{array}$ & $\begin{array}{l}40 \\
(0.220)\end{array}$ & $\begin{array}{l}82 \\
(0.326)\end{array}$ & $\begin{array}{l}38 \\
(0.200)\end{array}$ & $\begin{array}{l}21 \\
(0.104)\end{array}$ \\
\hline $\begin{array}{l}\text { At the end of } \\
\text { first month }\end{array}$ & $\begin{array}{l}66 \\
(0.241)\end{array}$ & $\begin{array}{l}31 \\
(0.164)\end{array}$ & $\begin{array}{l}76 \\
(0.319)\end{array}$ & $\begin{array}{l}17 \\
(0.071)\end{array}$ & $\begin{array}{l}13 \\
(0.063)\end{array}$ \\
\hline $\begin{array}{l}\text { At the end of } \\
\text { second month }\end{array}$ & $\begin{array}{l}103 \\
(0.352)\end{array}$ & $\begin{array}{l}33 \\
(0.196)\end{array}$ & $\begin{array}{l}52 \\
(0.268)\end{array}$ & $\begin{array}{l}9 \\
(0.036)\end{array}$ & $\begin{array}{l}6 \\
(0.017)\end{array}$ \\
\hline $\begin{array}{l}\text { At the end of } \\
\text { third month }\end{array}$ & $\begin{array}{l}134 \\
(0.537)\end{array}$ & $\begin{array}{l}36 \\
(0.241)\end{array}$ & $\begin{array}{l}28 \\
(0.134)\end{array}$ & $\begin{array}{l}5 \\
(0.019)\end{array}$ & 0 \\
\hline $\begin{array}{l}\text { At the end of } \\
\text { sixth month }\end{array}$ & $\begin{array}{l}160 \\
(0.755)\end{array}$ & $\begin{array}{l}28 \\
(0.210)\end{array}$ & $\begin{array}{l}12 \\
(0.041)\end{array}$ & $\begin{array}{l}3 \\
(0.011)\end{array}$ & 0 \\
\hline
\end{tabular}

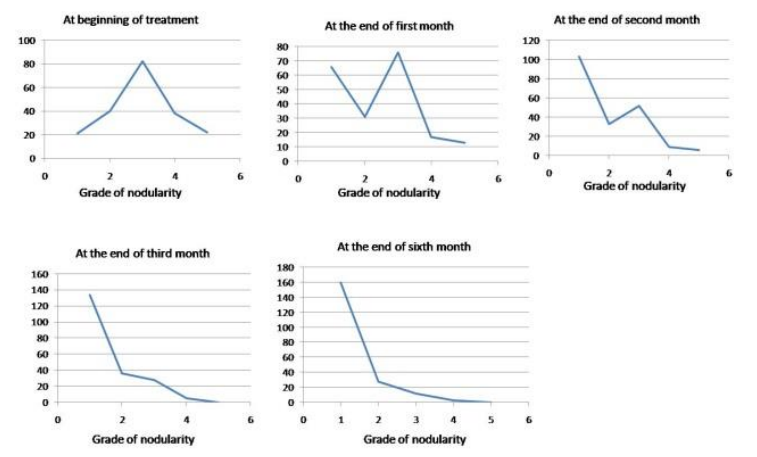

Figure 2: Cumulative changes of breast nodularity in all five visits.

\section{Side-effects}

There was no any major side-effect was reported by patients except for oligomenorrhoea in 9 patients and 3 was with mild headache.

\section{DISCUSSION}

Mastalgia as well as fibrocystic breast disease is a common complaint amongst women. Studies conducted on population based, and breast clinic-based ${ }^{10,11}$ studies suggest that up to $70 \%$ of women under 55 experience breast pain. Although $45 \%$ of them report minimal to mild symptoms, about $25 \%$ report moderate-to-severe mastalgia lasting for more than 5 days. ${ }^{2,8}$

This was suggested by review of the literature that the need to find a drug for mastalgia which is effective and safe. ${ }^{9}$ Several agents have been tried for mastalgia and fibrocysic. The two broad categories of drugs used are hormonal and non-hormonal. Hormonal manipulation has been done by using danazol, tamoxifen, bromocriptine, progesterone, oral contraceptive pill and more recently luteinizing hormone-releasing hormone (LHRH) analogue or goserelin. The non-hormonal agents used include analgesics (oral/topical), plant extracts such as fructus-agnicasti, EPO and and gamma linolenic acid (GLA).

Ormeloxifene (also known as centchroman) is one of the selective estrogen receptor modulators (SERMs), a class of medication which acts on the estrogen receptor. ${ }^{10}$ It is best known as a nonhormonal, nonsteroidal oral contraceptive which is taken once per week. Since the early 1990s in India, ormeloxifene has been available as birth control, and it is currently marketed there under the trade name Saheli. ${ }^{11}$ Ormeloxifene has also been licensed under the trade names NovexDS, Centron and Sevista.

The 1-isomer of ormeloxifene or levormeloxifene is more oestrogenic at the genital tract with much higher activity against ERs. It may be a useful drug for post-menopausal osteoporosis. However, it was not marketed because of the higher anticipated side-effects on the genital tract. No such side-effects have been reported for ormeloxifene even after its long-term use. ${ }^{12,13} \mathrm{~A}$ meta-analysis to evaluate drugs commonly used for the treatment of mastalgia was published. Several randomized, placebocontrolled trials were included in this metaanalysis. Seven trials on bromocriptine were analysed and the weighted mean difference in pain score in favour of bromocriptine was -16.31 (95\% CI -26.35 to -6.27 ) indicating a significant relief from mastalgia. Four trials of danazol showed a mean pain score difference of $20.23(95 \%$ CI -28.12 to -12.34$)$ showing its effectiveness in relieving breast pain. ${ }^{5}$

In our study we found that the mean pain score after three month was 1.21 and after six month (without treatment) it was 0.86 . Change in the grades of nodularity after six month was $92.6 \%$ with grades 1 and $2,7.4 \%$ with grades 3, 4 and 5. A study conducted by Sandeep Kumar et.al. reported about similar results i.e. mean pain score after three month was 1.39 and after six month it was 0.98 , grades of nodularity after six month $93.3 \%$ with grades 1 and 2 , and $6.7 \%$ with grades 3,4 and $5 .{ }^{14}$ A clinical trial conducted in All India Institute of medical sciences, New Delhi, India reported at the end of three month of treatmet $90 \%$ patients were pain-free with complete disappearance of nodularity. ${ }^{6}$ 
Tamoxifen thus is a useful and effective drug for the treatment of mastalgia and it is inexpensive too. However, it is also used as an anticancer agent too and hence patients are often concerned when asked to take tamoxifen. In addition, the above-mentioned drugs have several side effects. As bromocriptine $(2.5 \mathrm{mg}$ twice daily) causes headache, nausea, vomiting and dizziness. This led to a $20 \%$ dropout rate in some trials. ${ }^{6,7,15}$ Danazol (100-400 mg) results in weight gain, acne, greasy hair and skin, headache, nausea, hirsutism, decrease in the size of the breast and voice change (due to an androgenic effect). These side-effects occur in about one-quarter of patients. The incidence of amenorrhoea or irregular menstruation (due to gonadal suppression) increases at higher dosages of 400 to $800 \mathrm{mg}$. ${ }^{6,16}$ In our study there was no major side effect was identified except for oligomenorrhoea in 9 patients and 3 with headache while Sandeep et.al. found 12 patients complain by oligomenorrhoea but no evidence of headache was reported by any patients. ${ }^{14}$

\section{CONCLUSION}

As our study suggested there was significant improvement in mastalgia and fibrocystic breast disease in our patients indicates that SEVISTA (Ormeloxifene) is an effective agent for treatment of such patients.

\section{ACKNOWLEDGEMENTS}

We are very thanks full to Torrent Pharmaceuticals Ltd. (Prima) for providing drug SEVISTA (Ormeloxifene).

Funding: No funding sources

Conflict of interest: None declared

Ethical approval: The study was approved by the Institutional Ethics Committee

\section{REFERENCES}

1. Cooper A. Illustrations of the Diseases of the Breast, Part 1. London, England: Longman, Rees, Orme, Brown \& Green; 1829.

2. Ader DN, South-Paul J, Adera T, Deuster PA. Cyclical mastalgia: Prevalence and associated health and behavioural factors. J Psychocsom Obstet Gynecol. 2001;22:71-6.

3. Didsbury W. Aetiological factors in benign breast disease. Br J Surg. 1994;81:788-9.

4. Smith RL, Pruthi S, Fitzpatrick LA. Evaluation and management of breast pain. Mayo Clin Proc. 2004;79(3):353-72.
5. Srivastava A, Mansel RE, Arvind N, Prasad K, Dhar A, Chabra A. Evidence-based management of mastalgia: A meta-analysis of randomised trials. Breast. 2007;16:503-12.

6. Dhar A, Srivastava A. Role of centchroman in regression of mastalgia and fibroadenoma. World $\mathbf{J}$ Surg. 2007;31:1178-84.

7. Tejwani PL, Srivastava A, Nerkar H, Dhar A, Hari S, Thulkar S, et al. Centchroman regresses mastalgia: A randomized comparison with danazol. Indian J Surg. 2011;73:199-205.

8. Ader DN, Shriver CD. Cyclical mastalgia: Prevalence and impact in an outpatient breast clinic sample. J Am Coll Surg. 1997;185:466-7.

9. Santen RJ, Mansel R. Benign breast disorders. N Engl J Med. 2005;353:275-85.

10. Makker A, Tandon I, Goel MM, Singh M, Singh MM. Effect of ormeloxifene, a selective estrogen receptor modulator, on biomarkers of endometrial receptivity and pinopode development and its relation to fertility and infertility in Indian subjects. Fertility and Sterility. 2009;91(6):2298-307.

11. "HLL Product Overview" (http://www.hindlatex. com/TipsnGuidesdetails.aspx? valid $=1 \&$ category $=0 \& i d=170 \&$ type $=25$.

12. Vaidya R, Joshi U, Meherji P, Rege N, Betrabet S, Joshi L, et al. Activity profile of Centchroman in healthy female volunteers. Indian $J$ Exp Biol. 1977;15:1173-6.

13. Singh MM. Centchroman, a selective estrogen receptor modulator, as a contraceptive and for management of hormone-related clinical disorder. Med Res Rev. 2001;21:302-47.

14. Kumar S, Rai R, Agarwal GG, Dwivedi V, Kumar S, Das V. A randomized, double- blind, placebocontrolled trial of ormeloxofene in breast pain and nodularity. The National Medical Journal of India. 2013;26(2):69-74.

15. Gately CA, Mansel RE. Management of cyclical breast pain. Br J Hosp Med. 1990;43:330-2.

16. Hinton CP, Bishop HM, Holliday HW, Doyle PJ, Blamey RW. A double-blind controlled trial of danazol and bromocriptine in the management of severe cyclical breast pain. $\mathrm{Br} \mathrm{J}$ Clin Pract. 1986;40:326-30.

Cite this article as: Bansal V, Bansal A, Bansal AK. Efficacy of SEVISTA (Ormeloxifene) in treatment of mastalgia and fibrocystic breast disease. Int J Reprod Contracept Obstet Gynecol 2015;4:1057-60. 